\title{
How virtual fancy things build self-presentation? Consumer's acceptance and use of e-commerce
}

\author{
A.D. Yuniar \& A.S Fibrianto* \\ Universitas Negeri Malang, Malang City, Indonesia
}

\begin{abstract}
The virtual environment has been fast-growing as an ICT tool and making human life much easier. Industrial culture creates a "false need" for using ICTs because of mass production and passive consumer monopolies. The existence of "addictive behavior" about how the impact of smartphones and the internet is more complex for social change, especially lifestyle. This behavior then forms what Goffman called self-presentations. This paper used TAM grand theory of as the basis for its analysis element of perceived usefulness and ease of use which is important to consumers adopted the technology. Information richness has unlimited information as a form of unlimited consumer choices. The enjoyment of the performance industry will create a strategy that is not only informational but has an entertaining and enriching element.
\end{abstract}

Keywords: lifestyle, technology, e-commerce, society

\section{INTRODUCTION}

Most of modern society will answer the smartphone as a primary need. It cannot be denied when smartphones are now in line with cloth, food and shelter. After all, digital society necessities now depend on that one "smart" thing. This explanation implies that smartphones are a technology that embraces post-structuralism. This concept broadly states that technology is built-in with everything and become a part of modern society. People without hesitation in buying communication technology can be used as an investment, as evidenced by the emergence of technologies that continuously innovate, e.g., smartphones with advanced features and have high prices circulating on the broader community. The smartphone also raises attention in people seeing the extent of human efforts and following the trends they dream of. This trend can be seen when dressed up. This is reminiscent of a form of dramaturgy by Goffman. His self-presentation of everyday life sparked the term dramaturgy, which is how someone acts like they are on a stage. It implies that everyone wants to be the center of attention.

Since the existence of smartphones and social media, dramaturgy also exists in the social environment. If we do not know the latest trends which originate from social media, we can be "out of date." This drama then leads to the appearance; when people use a suitable fashion, it will be impacted through praise. (Ibrahim 2011) stated that we live where the standard of success is determined by materialistic prestige. Furthermore, (Hanson 2007) the existence of "addictive behavior" and "illusion of control" about how the impact of smartphones and the Internet is more complex for the social change of each individual, which is different on beliefs, attitudes, and values. Everyone takes part to show prestige values on how to appears image becomes more important than substance.' People no longer see the basic needs values, but the satisfaction value of getting them. It all depends on the perspective; some say that looking fashionable is a form of self-respect because most people say "you are what you wear." Thus, lifestyle is not only about people with financial

*Corresponding author: ananda.dwitha.fis@um.ac.id 
stability, but also people from the poor too. This lifestyle can then become a profitable commodity for the appearance industry. Along with the development of new media, the appearance industry business is increasingly emerging through e-commerce (e-comm). What technology and modernization offers is something real, and no one can hinder it. Whether people like it or not, people who live with ICT development will adapt to all modern treats. For this reason, this paper will discuss e-comm strategies that stimulate the consumptive lifestyle of modern society. This paper will also discuss what factors drive this consumptive behavior, with the following questions: How the online store market strategy encourages the consumptive lifestyle of modern society?

\section{METHOD}

This research is a conceptual-based article with a descriptive approach. This study focuses on the concept of self-presentation (Goffman) from a consumer perspective using the analysis of the Technology Acceptance Model Theory to see the consumer acceptance side of e-comm. The primary data is obtained from some e-comm market share, namely ZL, which focuses on the fashion industry, LZ, which focuses on the smartphone industry, and Go-Glam (part of Go) focuses on the service industry (method data market share) It is undeniable; some existing e-comm has changed consumer behavior to be addictive, especially in self-prestige and self-presentation.

\section{RESULT}

\subsection{Technology Acceptance Model (TAM) of consumer appearance industry}

To see the process of acceptance or adoption of an innovation in information technology by the public, a Technology Acceptance Model (TAM) model, derived from the grand theory of innovation diffusion, can now be used. The TAM model's choice is because diffusion and adoption theory is quite broad for the fields of producer marketing and consumer behavior since consumers play a role as an advantage of the marketing technology system. Research on the adoption and innovation of technology on consumer behavior has been conducted by Hwang and Jeong in 2014 on "Electronic commerce and online consumer behavior" which consists of technology in the form of features presented by the E-comm platform and also in terms of changes in the form of communication in modern society. This theory consists of 2 main factors, perceived usefulness related to the uses and benefits provided to e-comm to customers and perceived ease of use related to the ease of accessing and using e-comm technology. This two elements are useful for consumers to adopt the technology.

Virtual reality is a human way of visualizing, manipulating, and interacting with very complex computers and data (Piliang 2004). This virtual reality can carry out various interactive activities daily. This virtual reality then gives rise to what (Robins 1995) calls the digital environment as a collection of all events, facts, reality into something real. The digital environment has proliferated and powerful as an ICT tool capable of making people's lives much better and more accessible. The digital era changes people to become more fluent in using digital technology and they can actualize themselves to be always up to date. Furthermore, online shopping using an e-comm platform is becoming increasingly popular because of the effectiveness and ease of use for information and society (Yuniar \& Fibrianto 2019). Goffman also noted that sometimes an individual might be highly strategic in crafting an image but unaware that they create an impression as Gillette (Kucuk 2002) emphasized that the internet is playing a significant role in spurring consumerism by increasing consumer-driven market efficiency.

Perceived of usefulness, related to the uses and benefits provided to e-comm to customers. ZL can answer the needs of men's and women's fashion by offering leading brands, both local and international. ZL also always provides products that always follow the latest fashion trends that provide many choices to enhance consumer appearance. Various models of shoes, clothes, Muslim 
clothes, bags, accessories, batik, and sports as well as beauty \& grooming products for men and women, can be easily obtained. In addition, ZL Indonesia also provides flexible pricing options and often holds special promos with attractive discount offers through the newsletter that is displayed when opening the initial website appearance. Meanwhile, the element of perceived ease of use is related to the ease of accessing and using e-comm technology. ZL reates an attractive website so that many consumers are not bored. It has many advertisements with relevant information. When a consumer opens a link, the ZL website ad link will appear. ZL created the ZL website to easily access the products offered and to display all complete information about $\mathrm{ZL}$.

According to data obtained from the LZ website, the product with the most popular sales category is smartphones. If based on the value of goods, smartphones, including primary needs, are equivalent to clothing, food and shelter. Technology offered is increasingly sophisticated and makes it easier for people to mobilize. With prices that are still relatively high, people have now applied trust to e-comm without seeing the original physical appearance of the smartphone to be purchased. In the element of perceived ease of use, It presents various kinds of smartphone brands depending on the preferences of each consumer. They also provides reviews of each distributor that can be used as a guarantee of safety. Through the media website, LZ provides more in-depth and more flexible information about the form and benefits of a product. The role of website provides media to help consumers who are actively looking for the products they need. Based on the author's own experience, They create enough value and attraction for consumers who visit the site to stay and come back to make purchases. In this case continues to update their site to keep the site up to date. Whereas in the perceived usefulness element, LZ provides free shipping or cash on delivery using LZ Express for free and consumers just wait at home.

Go Glam is an extension of Go-Jek's business line that focuses on services. Initially, Go-jek focused as a facilitator between conventional motorcycle taxis and technology. However, along with market needs and the development of technology, Go expanded its business in the appearance industry. Through Go Glam, consumers don't have to bother coming to the salon and queuing for a long time. Simply by downloading the application, beauty services can be done at home or at the office. The beauty services provided by Go Glam include nail care, hair care, makeup, massage, facials, and so on. According to data obtained from the Go Glam application, the perceived usefulness for consumers includes high-quality services that guarantee the results will satisfy consumers. In addition, the operating hours are long so that whenever consumers need services, they will always be available. Then, guarantee high quality service because Go Glam works with professional beauticians who use quality products so they will provide the best service. The last benefit is that the professional partners who work with Go Glam have at least 2 years of experience and have gone through a long selection process. Whereas in the element of perceived ease of use, Go Glam provides a user-friendly application with a predominance of pink which is certainly very attractive to women. The application is also equipped with testimonials and video teasers of how Go Glam works professionally.

\section{DISCUSSION}

Ibrahim, in 2011, explained that the idea of a lifestyle has been corrupted by consumerism, thereby intending to commodify itself. According to Mowen and Minor (Punj 2011) consumerism is a community movement with government assistance to strengthen the rights and power of buyers in relation to sellers. Related to consumptive behavior is shopaholics in which consumers are "addicted" to shopping without thinking about the benefits of the goods they buy (Solomon \& Panda 2004). Thus, from the definition described above, it can be concluded that consumerism refers to consumer protection related to the consumer protection law, while consumptive refers to deviant behavior. This consumptive lifestyle then supports the appearance industry to provide and facilitate consumers with various innovation strategies. The strategies undertaken by e-comm owners are now increasingly unique and clever in offering their products with a lure that will certainly be tempting for those who see them. It becomes a further observation, where the "temptation" that 
comes from the online world, with all the conveniences offered, invites consumers to do things that shouldn't exist or need what they shouldn't need. The psychological condition of society that tends to be consumptive and this novelty is then taken advantage of by the appearance industry business manufacturers.

The consumptive lifestyle of the community in doing repetitive shopping is influenced by four elements, first, time saving where the e-comm digital catalog can present a variety of choices at one time. Consumers only need to scroll the page and place an order without the need to look for parking and long queues at the checkout which can take a long time. (Comor 2000) also explains that shopping via the internet can have high-speed communication in conveying understanding to consumers straightforwardly without spending much time searching for and making transactions related to products. In the context of the e-comm appearance industry, consumers can shop while doing other activities. It is different if consumers come to the store. Such as the features presented by ZL which have categorized their products such as shirts, blazers, heels and so on. So if consumers are looking for a blazer, just click on the category, and tens or even hundreds of blazers from various brands will be displayed on the page. Then consumers can choose according to their individual preferences.

Second, money saving because so many digital catalogs are presented, consumers can compare prices with one another. Then Ettenberg, in 2002, adds that simply making payments at home or at the office through online shopping can minimize expenses from one store to another. According to my argument, money-saving here means that consumers can save a number of their expenses for certain products because there are many price and quality comparisons according to consumer desires. However, this money-saving can also stimulate consumers to make purchases related to appearance. For example, if initially what consumers need is sports shoes, but in the catalog of all branded shoe products are discounting heels, wedges, and flat shoes, consumers can easily be tempted to buy sports shoes at first because the discounts in the same catalog consumers are willing to make repayment of products they do not need.

The final element of consumptive support is enjoyment, based on the concept of the appearance industry that society now prioritizes appearance over function, if external appearance is more important than the substance itself, the performance industry players will create a strategy that does not only contain information, but also has entertaining and enriching elements. In this context, after expanding its business, this application is increasingly attached and causes consumers to become addicted in utilizing the services offered ranging from food ordering services and beauty services. The digital appearance industry provides guarantee and security for the goods sold, this also encourages people's consumption behavior in shopping.

\section{CONCLUSION}

The whole appearance industry: e-comm e.g LZ, ZL, and Go Glam, takes advantage of market opportunities that currently focus on style-oriented society, where appearance is everything and appearance makes their existence in society even more "recognized." The issue of lifestyle now does not only belong to people with financial stability, some of those who live mediocre also have certain lifestyles. This lifestyle can then become a commodity and a big business for the appearance industry. Competition in business makes the appearance industry provide and facilitate consumers with various innovation strategies. The strategies undertaken by e-comm owners are now increasingly unique and clever in offering their products with the lure that will certainly be tempting for those who see them.

From the description above, the strength provided by the appearance industry is able to stimulate a consumptive lifestyle because of the time saving where the e-comm digital catalog can present a variety of choices at one time. Consumers only need to scroll the page and place an order without the need to look for parking and long queues at the checkout which take a long time. Money saving is also a factor because so many digital catalogs are presented, consumers can make price comparisons with one another. Information richness has unlimited information as a form of 
unlimited consumer choices. The enjoyment of the performance industry will create a strategy that is not only informational, but has an entertaining and enriching element.

\section{REFERENCES}

Comor, E. (2000) 'Household consumption on the internet: Income, time, and institutional contradictions', Journal of Economic Issues. doi: 10.1080/00213624.2000.11506246.

Ettenberg, E. (2002) The Next Economy: Will you know where your customers are?

Hanson, J. (2007) 24/7: How cell phones and the Internet change the way we live, work, and play. Greenwood Publishing Group.

Hwang, Y. and Jeong, J. (2014) 'Electronic commerce and online consumer behavior research: A literature review', Information Development. doi: 10.1177/0266666914551071.

Ibrahim, I. S. (2011) Kritik budaya komunikasi: budaya, media, dan gaya hidup dalam proses demokratisasi di Indonesia. Jalasutra.

Kucuk, S. U. (2002) 'The changing consumerism with the internet: a global perspective', Journal of Euromarketing, 12(1), pp. 41-61.

Piliang, Y. A. (2004) Posrealitas: realitas kebudayaan dalam era posmetafisika. Jalasutra.

Punj, G. (2011) 'Effect of Consumer Beliefs on Online Purchase Behavior: The Influence of Demographic Characteristics and Consumption Values', Journal of Interactive Marketing. doi: 10.1016/j.intmar.2011.04.004.

Robins, K. (1995) 'Cyberspace and the world we live in', Body \& Society, 1(3-4), pp. 135-155.

Solomon, M. R. and Panda, T. K. (2004) Consumer behavior, buying, having, and being. Pearson Education India.

Yuniar, A. D. and Fibrianto, A. S. (2019) 'The Affect of Technical Familiarity and Consumer Protection Behavior in Using E-Commerce as Platform Online Shopping', in Proceedings - 2019 International Seminar on Application for Technology of Information and Communication: Industry 4.0: Retrospect, Prospect, and Challenges, iSemantic 2019. doi: 10.1109/ISEMANTIC.2019.8884265. 